\title{
LEGAL STUDIES COURSES ENTERPRENEURSHIP, LEADERSHIP AND PROPAGATION IN SHAPING INTERREST AND DEVELOPMENT PATTERNS OF STUDENT ENTREPRENEURIAL LEGAL STUDIES
}

\author{
Aryani witasari \\ Sultan Agung Islamic University \\ aryani@unissula.ac.id \\ Masrur Ridwan \\ Sultan Agung Islamic University \\ masrurridwan4@gmail.com \\ Siti Rodhiyah Dwi Istinah \\ Sultan Agung Islamic University \\ s.rodhiyah@gmail.com
}

\begin{abstract}
To overcome the labor force in our country continues to increase from year to year, the government has transformed the world of education by requiring entrepreneurship education at several universities, including in Faculty of Law, Islam Sultan Agung Islamic University. Entrepreneurship courses, Propagation leadership and has even become one of the special compulsory curricula. The goal is that students thinking paradigm change, ie of thinking worker became the creator of the work. The mindset of the student is still dominated by the desire to be employees. Lack of motivation and interest in entrepreneurship is thought to be one cause their mindset has not changed. Conditions were not much different there as well may occur and are experienced by students of legal science education program undergraduate Sultan Agung Islamic University. Hopefully, the results of this study could also be input for the faculty of law, in particular lecturer entrepreneurship courses, the materials, and the learning process the eye teaching entrepreneurship suitable and appropriate for students of legal studies program undergraduate.
\end{abstract}

Keywords : Entrepreneurship; Form interests; Patterns of development.

\section{A. INTRODUCTION}

Anthony Robbins, a world-class motivator, in a seminar titled Unleash the Power Within, in Singapore in 2004, said that success is a person who can control feelings of pleasure and misery. ${ }^{1}$ when people it does not take the necessary steps to get a success, he will feel the pain of not

1 Fathur Rashid, Teri first, snapper Now !, First published Blue Book, Yogyakarta, 2010, P.5. willing to do the action. Instead, he will get a feeling of happiness when the necessary action to head success. ${ }^{2}$

When the Faculty of Law Unissula makes Entrepreneurship, Leadership, and Da'wah as one of the compulsory subjects ${ }^{3}$ for students of

2 Ibid.

3 Handbook for Academic Study Program (S1) Legal Studies,P.43. 
the undergraduate program of faculty of Law, certainly far from the intent of educating students to how future buy or sell a business out of legal cases related to membership or their science. Indonesian society difficulty finding a job, not least for college graduates, became one of the main considerations make KKDas one of the compulsory subjects in the legal studies program. Moreover, the number of unemployment in this country in the last three years (2016, 2017, 2018) never down from the range of seven million. On the other hand, the number of workforce per year continues to increase. Thus, the existence of teaching eye Entrepreneurship, Leadership, and Da'wah is part of one solution to overcome the gap between the availability of jobs, increase the workforce, and the chance of getting jobs for college graduates, not least for undergraduate education programs Legal Studies.

To answer the challenges above demands, wants and needs community expectations for educational services for their children, needed the abilities of the principal to have an entrepreneurial spirit innovate continuously. School productivity depends on the quality of the principal as a leading education, which moves the wheels institutions in scoring graduate's quality. ${ }^{4}$

Entrepreneurship, Leadership, and Da'wah legal study into compulsory subjects in the study undergraduate program Science Law, and how the process of changing

4 Budi Sutrisno, Anticipation Of Era Leadership Of The School Head of Entrepreneurship and Its Implications for Alumnus Supplementation in Accounting Education Products, Jurnal Pendidikan Sosial, Volume 27, Nomor 2, December 2017, P.10. paradigms of law students from job seekers into job creators, will be the focus of this study.

To contributing ideas of entrepreneurship courses development, as well can be input to the lecturer of the course in delivering teaching materials appropriate for students of legal science must be also related to the internalization of Islamic values in entrepreneurship.

As a college-based Islam, Islamic values in entrepreneurship should always be in the attached, as did Rasulullah in business, honest, polite, keeping promises, selling a good product, no business criticizing others, not hoard and keep times for worship. Everyone is seeing the personality and behavior of others is very different. So is the interpretation of others in judging what they have seen. ${ }^{5}$

\section{B. DISCUSSION}

\section{Legal Study for Law Students Unissula to Do entrepreneur After Taking a Course in Entrepreneurship, Leadership, and Propaganda}

Sultan Agung Islamic
University law students who
became the object of research is
students of legal science
undergraduate program (S-1),
which among other things are
designed and prepared to become
the next generation Khaira
Ummah, who mastered the science
of law universal equality, have an
entrepreneurial spirit, master the
basic values of Islam the noble

5 Ida Musofiana, Rizki Adi Pinadito, INCREASING CHILDREN'S CONSCIOUSNESS IN MOTORCYCLING OF MOTORCYCLE ON RAILWAY (study in Demak Regency), Jurnal Pembaharuan Hukum, Volume IV No. 3 September-Desember 2017, P.353-358. 
values of the Indonesian nation, uphold professional ethics, can speak English and ready to carry out the task of Entrepreneurship, Leadership, and Da'wah.

The object of research is student VI semester or more semester students on yet take courses Entrepreneurship, Leadership, and Da'wah. The course includes one of some special compulsory subjects are weighted two (2) semester credit units. Basic courses KK \& D as one of the compulsory subjects particular is Decision Dean Fakulatas Unissula Law No. 1524 / At / SA-H / VIII / 2018 regarding Guidelines Programs Academic Degree (S1) Law, Faculty of Law, Sultan Agung Islamic University (UNISSULA).

One of the principles that make a leader Unique entrepreneurship is that new way decision making is based on a different world view fundamental. Next is how to develop entrepreneurial leaders who are has a unique worldview, with a special focus on the concept of responsibility social, environmental and economic aspects sustainability and innovative ways to help entrepreneurial leaders understand the importance of a unique view of business and society. ${ }^{6}$

The target of the course delivery Entrepreneurship, Leadership, and Da'wah among others to equip students to have entrepreneurship and better prepared to enter the working

6 Safuan, Study In Literature Leadership In Entrepreneurship Facing Global Challenges, Jurnal Managemen Industri dan Logistik, Volume 1 Nomor 2, November 2017, P.176 world alternatively as a selfemployed can create their business activities, later when they have graduated and falls in the middle of society.

Number of students of the Faculty of Law Sultan Agung Islamic University (UNISSULA) which follows compulsory subjects specifically Entrepreneurship, Leadership, and Da'wah in VI semesters of school year 2018/2019 amounted to about 320 people, divided into four classes, where each class taught by a teacher, and each class is followed by around 80 (eighty) college student. Besides lecture material delivered face to face discussions, also with peel some cases or examples of successful entrepreneurs as a material world level studies and analysis of a success people have souls entrepreneurship. In the lecture after the implementation of the mid-semester, students are required to apply the theory that has been obtained by making appropriate business interests students in groups and present the results of his efforts.

Entrepreneurial leaders must operate from a different world view of business where they understand the tension that is inherent and potential synergies that exist between social, environmental and economic value creation. To do this they must also learn how to judge the interests, rights, and powers of a very diverse group from stakeholders. Entrepreneur leader needs to learn how to develop, implement, and measure the 
impact of a responsible solution and sustainable. ${ }^{7}$

Based on the foregoing, researchers presented the results of the analysis study below is based on the parameters of vision, mission and objectives of the Faculty of Law UNISSULA higher education law, especially in the "Produce a generation khaira ummah to master the science of law with equality universal, have an entrepreneurial spirit, master the basic values of Islam and or values Indonesia noble nation, upholding professional ethics .............. ". Giving eye Entrepreneurship, Leadership, and Da'wah lecture at the Faculty of Law UNISSULA expected to build soul entrepreneurship to students, to educate and develop the competencies of students, hope students can enter social relationships as self-actualization, and students have high confidence or not ashamed to face other people.

The student group is not a collection of human law which only contains robots that can diarahpoint granted. Students of the Faculty of Law UNISSULA composed of individuals of different desires and interests. Therefore a lecturer of a course should be able to direct all studentsDifferent interests and the desire to "move" toward a goal the convening of a course that is predetermined.

Wirawan define performance as an output produced by the functions or indicators of a job or a profession in a certain time. ${ }^{8}$ Some of the benefits gained by the student make the student feel fewer hours in the classroom and even their hope that the hour learning for entrepreneurship courses plus more. By accepting material Entrepreneurship, Leadership, and Da'wah students can apply leadership behavior in everyday life. Even with the receiving eye Entrepreneurship, Leadership, and Da'wah Class also affect the attitudes and views of Student Life. It makes students want to start a business, and students began has a view of life to plan for the future, such as being lawyers or notaries who have a specific business. The Concerted effort to opening a business is going to be a special process, gradually and later will balance the quality of products to compete, as well as more apply the value of creativity to make innovations to a product or business.

Law students have a good life, most have a strong urge to do or have entrepreneurial activity, they want independent because the entrepreneurial spirit in the form of their independence can produce/channeling the creativity they have. They need to convince the people parents if they do not agree to his son open a specific business. Approach persuasive manner they did a good way of communicating with party family and promise that what they run does not interfere with their course

8 Johan Gunady Ony dan Micheline Rinamurti, Autocratic Leadership And Entrepreneur Competency In Family-Based Companies (Study On Special Culinary Business, Palembang), Seminar Nasional and cal for paper Manajemen, Akuntansi dan Perbankkan 2018, P.200. 
and promised to pass on time. Some of the students desirous to be able to start entrepreneurship since the moment sauce sticking to college, but many want after graduation for fear of not untill college graduation. Actually, after of me when they can start a business it is not urgent, wich important in their lives has been embedded to be willing someday to have a particular business.

In the time they start a business, students can involve close relative's own, such as parents, relatives family, community friends, classmates and other's dedication and commitment to the goals to be achieved.

Leadership development the entrepreneur above and respond to its growing demands and challenges in this globalization era, it is expected a generation of qualified leaders is created Entrepreneurial leadership. ${ }^{9}$

An entrepreneur must be able to unite the various experiences, past, culture, habits, perspectives, and other characters that vary between member family, friends, and neighbors with each other. One key to the success of an entrepreneur is the ability to bridge differences, and making as a synergistic force.

\section{a) Family Experience.}

All

respondents recognize, at an early stage it is not easy to build a business, most do not require sufficient time. For that, we need to provide insight to all members

9 Wahyu Purhantara, Indonesia Business Leadership in The Free Market Era, Jurnal Ekonomi and Pendidikan, Volume 7 Nomor 1, April 2010. of the family and those closest, why the need to pioneer or build their own business, so that in the end they could understand and adjust to the willingness of respondents. Family experience also very affects the decision to be taken, respondents.

\section{b) Difficult Started a Business}

Almost all respondents stated how difficult it is to start a business or become entrepreneurs, but have also stated not difficult as long as there is courage, daring hold shame, and pride and have enough capital to get started and be willing risk can not be the way business.

Confused determine what option would be to do business it is also one-factor difficult start efforts. already available, the time has also been designed to provide, power has been thinking conceivable, but the idea of doing business that if it can be done has not been met as well, eventually protracted not do a particular effort as in the aspired.

Several factors can affect entrepreneurial success include Personal factors (concerning aspects of one's personality), experience, leadership, culture company organization, motivation, environmental (concerning relationships with the environment), education level. ${ }^{10}$

10 Noneng Masitoh, and Heri Herdiana, Influence of Entrepreneurship Leadership, Motivation and Environment Embroidery Business Productivity in Kawalu District Tasikmalaya City, Jurnal Ekonomi Manajemen, Volume 3 Nomor 2, 2017, P.115. 


\section{Guidance Pattern for Students Against the Law Faculty entrepreneurship}

Leader criteria must be seen from the cognitive side. Intellectual stimulation is one dimension of leadership characteristics, which is trying to create a climate which is conducive to the development of innovation and creativity. ${ }^{11}$ Development patterns that researchers have to offer is a pattern that is a pattern formation think. That's because of the initial orientation of research about the mindset and behavior of the individual undergraduate student of jurisprudence Unissula Semarang. How entrepreneurial mindset student of law can be synchronized with their entrepreneurial behavior, and a touch of Islamic values, so that in time later, output from undergraduate jurisprudence Unissula not to "slip" or "slip" on the concept law entrepreneurship that contrary to the guidance of Islam and contrary to other norms, including legal norms.

The speed of that change faced by various adult organizations This has made many people called for the need for more adaptive leadership and flexibility. Adaptive leaders will work more effectively inside a constantly changing environment continuously by understanding the challenges and the growth that leaders face and then give a response right against that challenge. Leader the

11 Wahyu Purhantara, Indonesia Business Leadership In The Free Market Era, Jurnal Ekonomi dan Pendidikan, Volume 7 Nomor 1, April 2010, P.23 adaptive ones will collaborate with their followers to create solutions who are creative for various problems that are complex and at the same time develop themselves so they can handle more leadership responsibilities wide reach. ${ }^{12}$

3. Development patterns that researchers have been adapted to offer conclusion research which refers to the interpretation of the results of qualitative research, which originally was expected to explain the orientation of the entrepreneurial spirit of students of legal science after receiving materials Entrepreneurship, Leadership, and Propagation. In Language simple, Faculty of Law Unissula does not want output- misrepresenting his or interpret law entrepreneurship with "trade-in law", wherever it later their career.

The positive impact of principles entrepreneurial leadership according to Roebuck as quoted by Zwilling ${ }^{13}$ :

a) Total focus on service to customers

12 Siti Hajar, Rahman Lubis, Permana Honeyta Lubis, Influence Of Leadership And Trust Behavior Towards The Performance Of The Social And Labor Service West Aceh District Transmigration, Jurnal Magister Management Faculty of Economic and Bussines Unsiyah, Volume 2 Nomor 1, January 2018, P.48.

13 Zwilling, Martin. 2014. Entrepreneurial Leadership Can Save Any Business. http://www.forbes.com/sites/martinzwilling 12014/09/17/entrepreneurial-leadershipcansave-any-business/. accessed on Agustus 2019 
Each team member is activated close to the line front of customers, so they see how each function works or not in providing value-added services they provide to customers. People in larger organizations move away from day today make contact with consumers, and finally, the company's focus becomes internal and isolated.

\section{b) Optimize risk, no minimize it}

The calculated risk must be taken to allow change, to improve, and make ends meet a new customer. Minimize risk to will eventually cause every the company to fail. An error will happen, so the goal doesn't have to be for eliminating all mistakes, but to catch them before they create a disaster, and be repetitive.

c) Continue to be creative and innovative to get who better

\section{Mature organizations}

forget that change is an opportunity, not a threat. However, no one is still aware of. Change allows everyone to pushing boundaries at response, to increase their opportunities for self-growth, improve position competitive companies and opportunities for long-term success.

The problem is how far in the country this is experiencing a leadership crisis governance. The term crisis is for marks how acute decadence governance from a leadership perspective. Here and there the public leader was caught corruption, immorality, and so on. ${ }^{14}$

Based on the above reasoning, the researchers offer guidance patterns are:

a) mental development entrepreneurship and soul intrapreneurship.

The fundamentalist to develop the entrepreneurial spirit dimension consistent with Islamic guidance. That in fact in entrepreneurship there is entrepreneurship, the entrepreneurial spirit that can be applied wherever they career; well as judges, prosecutors, police, civil servants, private employees, and others, even if they don't start a business. Embed/motivate students to mentally winners (the winner), not mentally losers (the loser).

b) Motivate students to think positively (positive thinking), so that they are ready to jump into real life and compete in the competition of life more stringent.

c) Introducing students with several entrepreneurs who considered successfully building businesses and give them the opportunity discussion directly, to then continue with the discussion in the classroom, on the results that they can as long as they interact with some businessman/company is considered a success.

14 Sutiyo, Application Of Business Entrepreneurs In Leadership Government, Jurnal Ilmu Politik dan Kaomunikasi, Volume 7 Nomor 1, June 2017, P.72 
d) Together students with religious leaders who judged more competent explain entrepreneurial values from the viewpoint of Islam.

Leadership in the Asian region is growing with enthusiasm religious background, beliefs, and social values shared by local community. In particular, leadership in Asian society very related to local culture Public. Local culture of the community become the basis of the concept of leadership what the local community wants the. Therefore, leadership in Asian society is often known as cultural leadership. That is, the criteria for effective leadership measured the extent to which the leader is able maintain and implement local culture of the community. They views maintaining importance their local culture, because contains values, norms, and trust about relationships humans with nature, others, and God is believed to be the 'soul' they reach life goals. ${ }^{15}$

\section{Learning model}

a. There is a target on any of the material presented to students; by always linked with the commands and prohibitions, both from the viewpoint of Islam and law.

b. A professor or teacher Entrepreneurship, Leadership, and Da'wah in meetings or face to face with students is expected to generate interest in

15 C. Budi Santoso, Exploration Of Asia Leadership Theory: Looking For An Asian Role In The Field Of Leadership Theory, Journal of Leadership in Organization, Volume Nomor 1 Nomor 1, 2019, P.68 student life will the values of entrepreneurship in a broad sense.

c. Every now and then bring alumni who managed to build a business and tell the success (or failure) they have ever experienced, and give student opportunities have a live discussion with the "seniors" who managed to build a business.

d. Provide practical knowledge provision, by making previously held thinking world business leaders (both Muslim leaders and non-Muslims) as one reference materials.

e. Assigning students flocking 4-5 conduct business activity with a certain pre-determined capital, the lecturer will provide an assessment towards creativity and effort of students in the fight against shame and risk that may occur.

f. Entrepreneurship, Leadership, and Da'wah teaching material combines with some eye department of science teaching the relevant law (such as procedural law, mediation skills, capital markets law, etc.), by giving assignments to students.

Every organization, in general, expect to have quality human resources and highly competitive so that it can carry out their duties effectively, productive, and professional to advance organization. Humans as one Organizational resource are very important in realizing organizational goals because humans in doing activities inside the organization are realized through work, talent, creativity, 
and tangible roles that can be measured its productivity. ${ }^{16}$

The learning model the values of entrepreneurship to students of science study program undergraduate (S1) UNISSULA law should use approaches and methods vary. As far as possible in every class meeting, students can be motivated and keen to continue fostering the entrepreneurial spirit which was deliberate to grow properly.

In developing competence
(empowering)
businessman should not only think about them selves but also act as if as a manager for an organization. A prospective employer must understand themselves, the needs of the surrounding, the environment, and so so.

The student in order to increase the competence of selfmade by digging further still lacking competence, enhance the competence themselves by focusing in a professional manner, and need pay attention to increased ability to achieve better results.

The implementation of innovative leadership, and determinant factors of such leadership to be applied within the public policy. ${ }^{17}$

Many ways can be done by the students to motivate

16 Agus Yudi Harsono, Supratomo, Muhammad Farid, Analysis of Leadership and Communication Organization Between The Top-Down in Building Organizational Culture in The Environment DPRD Secretariat of City of Bengkulu, Journal Komunikasi KAREBA, Volume 4 Nomor 3, September 2015, P.329

17 Muhammad Ramli, Innovative Leadership in Implementation of Makassar City Strategic Policy, Journal Politik Profetik, Volume 5 Nomoor 2, 2017, P.168 themselves in entrepreneurship, among others, by establishing social relationships outside the community is very important for an entrepreneur. An employer must not only glue the environment is very limited, but it should also give attention to the surrounding environment as business development targets. Interwoven interaction starting from the closest family relationship alone, and friends around the neighborhood live and housed. There's even stated that the fabric of interaction with parties outside the family still has not been done in a planned manner. they simply do away with it, there are no specific rules. In terms of academic organization and spiritual. But because social media is easier to do, then they interact through Social Media.

An entrepreneur must be able to build trust. But not mixing between trust with friendship. Build intimate relationships with all parties will automatically make a lot the trust businessman The. Conversely, build and develop trust (trust dimension) or be open to all parties will make them learn how to build trust through cooperation in work experience.

For the sake of equipping students to be successful in the future, then the student needs to prepare to adapt or conform to cultivate openness and the demands of the times. Transparency is built with honesty to address the problem, always open to suggestions and criticism from various circles, and does not hesitate to ask for consideration of various circles. other than that also by making sure all the info in for to various groups, to ensure that all 
existing events record her, made a chronological if in some cases need to respond quickly.

An undergraduate student group jurisprudence Sultan Agung Islamic University (UNISSULA), Hyderabad is comprised of individuals who are different desires and interests. Lecturers of the course are expected to directing all students of different interests and the desire to "move" toward the purpose of convening a course that has been previously set.

Based on in-depth interviews and observations that researchers do to respondents about level successful delivery destination college convening of an eye, in terms of the course material Entrepreneurship, Leadership \& Propagation, can be seen or measured from the level of understanding or absorption of respondents over entrepreneurship, Leadership \& Propagation materials delivered by lecturers. In the context of course entrepreneurship, Leadership \& Propagation respondents stated to understand the existence of subjects entrepreneurship, Leadership \& Propagation, and respondents were introduced to the business world based on the values of leadership and Islam. But the statement "Do not know" can not be interpreted as not understand or do not understand the same once. Regarding the level of students understanding of the subject entrepreneurship, Leadership \& Propagation can be seen from their understanding of the entrepreneur criteria, type of business, soul entrepreneurship and others that must be owned by a person at the time he would start running the business. On the usefulness of entrepreneurship, Leadership \& Propagation subjects for student law, all respondents agreed to declare very usefully and important. apart from directing students to have mindset astute businessman catch business opportunities in the surrounding environment, it also teaches students to become entrepreneurs who adhered to the law. Some respondents expect that portion of the course entrepreneurship, Leadership \& Propagation plus, as delivered.

Course materials entrepreneurship, Leadership \& Propagation perceived by law students UNISSULA further open their minds about the world of business, entrepreneurial insight, andentrepreneurship a good way. They become more excited about the future front, and can directly apply leadership skills in the daily livesdays, after receiving the teaching materials entrepreneurship, Leadership \& Propagation can apply leadership attitudes, andcan be applied in everyday life. Over the course entrepreneurship, Leadership \& Propagation bring an influence on student attitudes and outlook on life will be pastfront. UNISSULA law student response to the entrepreneurial spirit diverse. But the average respondent, except one, expressed very well and interested.

Being an entrepreneur or open a business is certainly not easy. There ismany obstacles or barriers that must be traversed. One of them came from membersfamily, family members 
who want to build his career in governmentor would become one of the officials of government/public. Facing the challengeThey have almost all the respondents, including one who is not

interested

rslespondenentrepreneurship, said it will convince and prove to the family that's their choice to become self-employed is very precise.

At the core of all respondents would establish a better communication with of members of his family who objected to measures business options and the future they would choose. Start building or planting a business, it certainly can not be done one, because it must involve many parties. Most do not have to involve those nearby, be it parents, family, friends, or couples. UNISSULA law students prefer involve people who havecommitment and dedication to the goals and targets, although with others.

How to implement the measures synergy among families, each respondenthave a unique style. For routine activities or sharing This, they also has a style and way respectively. Among others simply walk forfamilies who happen to parents who loved the streets, there is every day is alwaysany story to parents, there are regular (often) video call with family, becausehe was a student boarding house, spending time together, and others, dependinghabits of each. One respondent claimed that since the beginning of the relationshipless good antarkeluarganya asserted, "no". Their communication with Family members include a plan to open a business in the future, and plans activities to be implemented. About who is the most dominant in the family, the majority of respondents point mother figure as the most dominant figure in the family, rated the first, followed by the father ranks second, only parents with no specific mention father or mother. An employer is generally less attentive to environmental activities, except for activities that are considered to be beneficial.

Whereas an entrepreneur should also pay attention to environmental activities around, more than ordinary people so that an entrepreneur always motivated to do more. How respondents or legal science students motivate themselves UNISSULA very diverse. Some claimed that he had done CMC (coaching, mentoring, counseling) with family, there is said never, and etc.

\section{CONCLUSION}

Entrepreneurship, Leadership, and Propagation legal study into compulsory subjects in the study undergraduate program (S1) Law, and how the process of changing paradigms of thinking student law of job seekers into job creators, not just law entrepreneurship, yielded some interesting findings, particularly when this study also attach Islamic values as the philosophical basis expected to prevent output Prodi of Law UNISSULA of things that are not expected when they later plunge in the business world. Most student's science law being changed their perspective of the future will they live, after receiving instructional materials Entrepreneurship, Leadership, and Propagation. Students with 
backgrounds family employers more secure in his choice to become entrepreneurs, students who do not have a family background of the entrepreneur, started to become more open to their way of thinking about entrepreneurship Islamic. students also increasingly understand that being an entrepreneur is part of the values taught by Islam. Development patterns might include the development of the soul entrepreneurship and oul intrapreneurship, motivate students governmental winner (the winner), not mentally losers (the loser), Motivate students to think positively (positive thinking), introduce students to some of the entrepreneurs who are considered successful, together students with religious leaders are more competent explain entrepreneurial values from the view point of Islam.

\section{BLIBIOGRAPHY}

\section{Book:}

Agus Yudi Harsono, Supratomo, Muhammad Farid, Analysis of Leadership and Communication Organization Between The Top-Down in Building Organizational Culture in The Environment DPRD Secretariat of City of Bengkulu, Journal Komunikasi KAREBA, Volume 4 Nomor 3, September 2015;

Budi Sutrisno, Anticipation Of Era Leadership Of The School Head of Entrepreneurship and Its Implications for Alumnus Supplementation in Accounting Education Products, Jurnal Pendidikan Sosial, Volume 27, Nomor 2, December 2017;

C. Budi Santoso, Exploration Of Asia Leadership Theory: Looking For An Asian Role In The Field Of Leadership Theory, Journal of Leadership in Organization, Volume Nomor 1 Nomor 1, 2019;

Fathur Rashid, 2010, "Teri first, snapper Now !", Blue Book, Yogyakarta;

Handbook for Academic Study Program (S1) Legal Studies. The Central Bureau of Statistics;

Ida Musofiana, Rizki Adi Pinadito, INCREASING CHILDREN'S CONSCIOUSNESS IN MOTORCYCLING OF MOTORCYCLE ON RAILWAY (study in Demak Regency), Jurnal Pembaharuan Hukum, Volume IV No. 3 September-Desember 2017;

Johan Gunady Ony dan Micheline Rinamurti, Autocratic Leadership And Entrepreneur Competency In Family-Based Companies (Study On Special Culinary Business, Palembang), Seminar Nasional and cal for paper Manajemen, Akuntansi dan Perbankkan 2018;

Muhammad Ramli, Innovative Leadership in Implementation of Makassar City Strategic Policy, Journal Politik Profetik, Volume 5 Nomoor 2, 2017; 
Noneng Masitoh, and Heri Herdiana, Influence of Entrepreneurship Leadership, Motivation and Environment Embroidery Business Productivity in Kawalu District Tasikmalaya City, Jurnal Ekonomi Manajemen, Volume 3 Nomor 2, 2017;

Safuan, Study In Literature Leadership In Entrepreneurship Facing Global Challenges, Jurnal Managemen Industri dan Logistik, Volume 1 Nomor 2, November 2017;

Siti Hajar, Rahman Lubis, Permana Honeyta Lubis, Influence Of Leadership And Trust Behavior Towards The Performance Of The Social And Labor Service West Aceh District Transmigration, Jurnal Magister Management Faculty of Economic and Bussines Unsiyah, Volume 2 Nomor 1, January 2018.

Sutiyo, Application Of Business Entrepreneurs In Leadership Government, Jurnal Ilmu Politik dan Kaomunikasi, Volume 7 Nomor 1, June 2017;

Wahyu Purhantara, Indonesia Business Leadership In The Free Market Era, Jurnal Ekonomi dan Pendidikan, Volume 7 Nomor 1, April 2010.

\section{Website:}

Understanding Propagation in view of Islamic Law, Culture and the Qur'an, www.ineurekapendidikan.com

Zwilling, Martin. 2014. Entrepreneurial Leadership Can Save Any Business. http://www.forbes.com/sites/martinzwilling/2014/09/17/entrepreneurialleadership-cansave-any-business/ 